\title{
An Ethnobotanical Survey of Medicinal Plants used in the Preparation of "Atikédi": Local Alcoholic Beverages Commonly Consumed in Lomé Togo
}

\author{
Afanyibo Yaovi-Gameli, \\ Koudouvo Koffi, \\ Esseh Komlavi, \\ Agbonon Amegnona,
}

Laboratory of Physiology and Pharmacology, Faculty of Sciences (FDS), University of Lome (UL), Bvd. Gnassingbe Eyadema, Togo, Center for Research and Training on Medicinal Plants (CERFOPLAM), UL, Bvd.

Gnassingbe Eyadema, Togo

Tozo Koffi,

Plant Biotechnology Laboratory, Department of Botany,

FDS, UL, Bvd. Gnassingbe Eyadema, Togo

\section{Gbeassor Messanvi,}

Laboratory of Physiology and Pharmacology, Faculty of Sciences (FDS), University of Lome (UL), Bvd. Gnassingbe Eyadema, Togo, Center for Research and Training on Medicinal Plants (CERFOPLAM), UL, Bvd. Gnassingbe Eyadema, Togo

Doi: 10.19044/esj.2018.v14n33p1 URL:http://dx.doi.org/10.19044/esj.2018.v14n33p1

\begin{abstract}
Ethnobotanical relevance: Local alcoholic beverages "Atikédi" are produced in Lomé and consumed not only for pleasure but also for therapeutic purposes. They are produced out of "Sodabi", distilled palm wine, mixed with plant organs. However, the exact composition of these beverages and the diseases they are supposed to treat are poorly documented to date in Togo. Aim of the study: To make an inventory of plants used by "Atikédi" beverages producers in Lomé. Materials and methods: Data collection was made through Semi Structured Interview. Data processing and analysis were done using Excel and Epi Info. Results: 267 outlets were identified with a predominance of stores (53.18\%). 192 women and 75 men were interviewed. They belonged to 12 different ethnic groups with the majority being Ewe (127) and Ouatchi (71). Their age range varied from 25 to 70 years with an average of $42.6 \pm 7.9$ years. 61 plants species were recorded belonging to 58 genera and 35 families. The most represented
\end{abstract}


family was the Apocynaceae with five species followed by the Rutaceae and the Poaceae with four species each. Among 43 diseases managed by the plants, bacterial infections $(\mathrm{ICF}=0.95)$ and sexual weakness $(\mathrm{ICF}=0.95)$ were the most important pathologies. Conclusion: Producers of "Atikédi" used a wide range of medicinal plants. Pharmacological and toxicological studies of these plants will improve the quality of care provided by traditional medicine.

Keywords: Ethnobotany; Medicinal plants; Alcoholic beverages "Atikédi"; Lomé Togo

\section{Introduction}

Togolese, as any other people in the West Africa subregion, use traditional medicine for primary health care (Kpodar et al., 2016, Gbekley et al., 2018) despite the progress of conventional medicine in the management of diseases. Previous studies have shown various forms of preparation of plant products with various extraction solvents (Koudouvo et al., 2011). Alchoholic beverages are among the most common solvents used by traditional healers. These drinks, which are a priori consumed for pleasure, serve a posteriori as a solvent in the production of some phytomedicines (Totelin, 2015).

The consumption of alcohol drink is an old practice of many ethnic groups in West Africa and in South America. In Togo, the Ewe and Ouatchi people have been since the pre-colonial period, well-known for the production of a local alcohol drink called "Sodabi", produced out of artisanal distillation of fermented palm wine. It has different names depending on the country: "Sodabi" mostly being used in Benin and Togo, Ondotol or hâ in Cameroon, Koutoukou in Côte d'Ivoire, Akpeteshie in Ghana, Ogogoro in Nigeria (Tchacondo et al., 2011).

Once the beverage is prepared, people infuse for a few days, roots, barks or leaves of plants to give it a taste or medicinal properties. The beverage, far from being a simple alcoholic beverage, becomes a traditional liquor called in local name Ewé "Atikédi" which means etymologically "containing drug". This practice of mixture of "Sodabi" with plants used for therapeutic purposes is therefore an integral part of traditional medicine. It is widespread in Lomé and is sold in kiosks all over the city.

It is important to look into this type of phytomedicines to ensure the quality of care they provide to the population. In addition it is necessary to explore all areas where tradional medicine is practiced (Kunwar et al., 2009).

Many studies about alcoholic beverage have been undertaken around the world: Bitter-cups by Odonne et al. (2006) in Suriname; Jamaican root 
tonics by Mitchell (2011); Tifey by Volpato et al. (2008) in Cuba. However, no ethnobotanical study until today, has been conducted among producers of local beverage "Atikédi" in Togo. Ethnobotanical surveys may be therefore a good approach to drug discovery (Koudouvo et al., 2016; Umair et al., 2017). Thus many compounds have been discovered from plants based on ethnobotanical survey information (Attah, et al., 2016).

What are the medicinal plant compositions of these beverages? What diseases the plants are supposed to treat? These questions stand for the rationale for the conduct of this research. We expected this practice would certainly overflow information whose knowledge will improve the quality of care given by traditional medicine. In this respect, this survey was conducted to prospect "Atikédi" producer's herbal medicine practices in Lomé. The specific objectives were (i) to identify plants species used in the production of the alcoholic beverages "Atikédi" in Lomé and (ii) to identify the ailments treated by plants species in order to contribute to the progress of the traditional medicine.

\section{Methodology}

\section{Description of the study area}

The study was conducted in Lomé, the capital city of Togo, a Western African country with a population of 6,191,155 inhabitants and a density of 109 inhabitants per $\mathrm{km}^{2}$ (DGSNA Togo, 2011). The country shares borders with Burkina Faso in the North, the Gulf of Guinea in the South, Benin in the East and Ghana in the West. It is divided into five economic regions namely Savannah Region, Kara Region, Central Region, Plateaux Region and Maritime Region (Fig. 1). Many languages are spoken in Lomé but the most popular are Ewé and Mina.

Lomé lies between latitude $6^{\circ} 08^{\prime} 14^{\prime \prime}$ North, longitude $1^{\circ} 12^{\prime} 45^{\prime \prime}$ East and an average altitude of $10 \mathrm{~m}$. It sprawls along the coast of the Gulf of Guinea and covers an area of $90 \mathrm{~km}^{2}$ with a population of 837,437 inhabitants, a density of 9305 inhabitants per $\mathrm{km}^{2}$ (DGSNA Togo, 2011). The climate is subequatorial. Lomé is surrounded by the Maritime Region towards North and East, Ghana towards West and the Gulf of Guinea towards South. Lomé is composed of five Districts namely $\mathrm{N}^{\circ} \mathrm{I}$ to $\mathrm{V}$ (Fig. $1)$. 


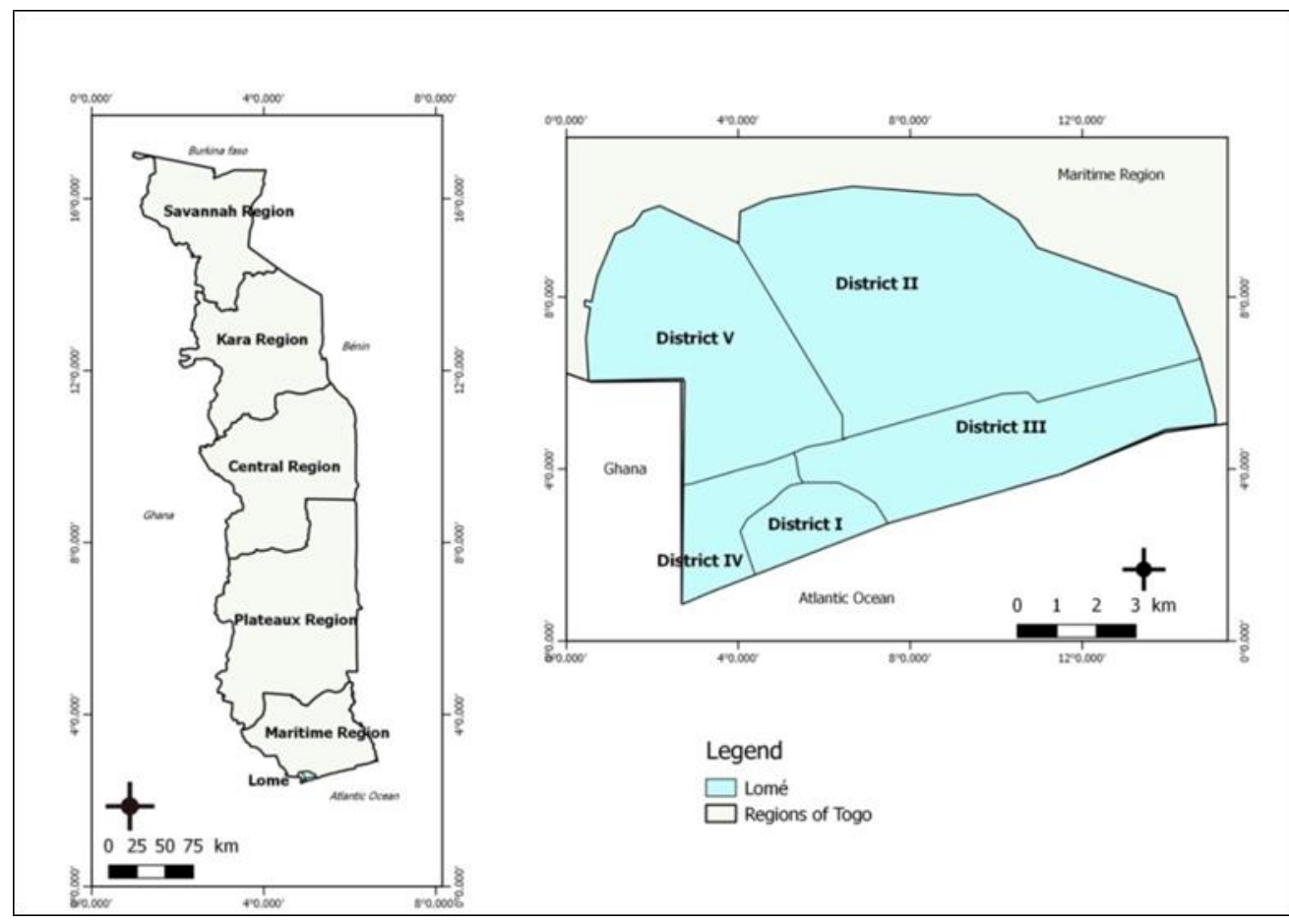

Fig. 1. Map of the study area (Performed by QGIS software)

\section{Data collection}

The ethnobotanical survey was conducted from March to October 2015 in Lomé. All interviews were conducted in Ewe, Mina and French. The data was collected from kiosks owners who produce beverages on site by infusing plant organs into Sodabi, the local alcoholic drink, for a few days before serving to their clients. We conducted a census of all beverage outlets in Lomé by Semi-Structured Interview method (Koudouvo et al., 2011, Soejarto et al., 2012). During this survey, the main information focused on sociodemographic data, plant species, plant parts used and diseases treated. Each person in charge of a point of sale was questioned so that the number of points of sale corresponds to the number of respondents. The plant organs used were known from the respondents' answers. They had answered mainly to the questions relating to the name of each beverage sold, name of the plants and organs of plants used, diseases against which the beverages are consumed. Each respondent was interviewed two or three times a week in his shop and there was no consensus between them during the census.

Plant species were collected in October 2015 considering their vernacular names, with a the help of four informants. Three informants were beverages producers who had indicated to us most of the plants involved in the preparation of these beverages. The last one was a knowledgeable local 
person who helped us to obtain more information particulary on plant habitat (Balayogan et al., 2014).

The plants were collected in Lomé and in two villages in the Maritime Region : Wogba and Tabligbo.

\section{Plant identification}

Herbarium specimens were prepared and pictures of the plants were taken. Plants were identified through comparison with available voucher specimens at the Herbarium of the Department of Botany, Faculty of Sciences, University of Lomé using taxonomic keys of online databases of West African Plants: http://www.westafricanplants.senckenberg.de/root/index.php. Nomenclature of species was done using the International Plant Names Index (IPNI) online database: http://www.ipni/plantnamesearchpage.do.

A specimen of each plant was deposited at the Herbarium of the University of Lomé and a voucher specimen number was assigned to each plant.

\section{Data analysis}

Data processing and analysis were carried out using Epi Info 3.5.1 software. The map was designed by QGIS software.

The informant consensus factor (ICF) was calculated for each disease treated to improve the consensus of the informants on the reported plant species. It was calculated as follows:

ICF $=\frac{\text { Nuc-Ns }}{\text { Nuc-1 }}$ where Nuc was the number of citations of each disease treated; Ns the number of species used (Heinrich et al., 1998; Njoroge and Bussmann, 2007). The ailments were grouped per category according to Balayogan et al. (2014).

\section{Results}

Sociodemographic data

The sociodemographic data of the respondents are displayed in Table 1. Among the total of 267 producers interviewed, were 75 males and 192 females. Their average age was 42.6 years with a standard deviation of 7.9 years. The youngest was 25 and the oldest was 70. Half of the respondents were aged between 38 and 50. The 30-40 age group was the most represented with $44.6 \%$ followed by the $40-50$ age group with $34.0 \%$. The respondents belonged to 12 different ethnic groups. The majority were Ewe (127) and Ouatchi (71) followed by Adja (33) and Mina (20). The other ethnic groups were less important in size. The combined size of EweOuatchi ethnic groups was $74.2 \%$. The seniority of the respondents ranged 
from 9 months to 20 years' experience in the production and sale of the beverages "Atikédi". The majority had 5 to 10 years' experience (90). Most of the producers $(79.0 \%)$ mentioned family inheritance as the main source of their knowledge of medicinal plants.

Frequency of plants species and disease treated

The scientific and vernacular names, voucher specimen number, habitat, parts used, frequencies of citation, and medical uses of the 61 medicinal plant species recorded in this study are reported in Table 2.

The frequency of citation was high for Mondia whitei $(75.28 \%)$ and Khaya senegalensis (56.18\%). It is followed by Sorghum caudatum (38.20\%), Phyllantus amarus (36.33\%), Caesalpinia bonduc (34.83\%), Nauclea latifolia (32.21\%), Syzygium aromaticum (26.97\%), Conyza aegytiaca (25.84\%) and Aframomum melegueta (24.72\%).

Infection $(\mathrm{Nu}=668)$ and sexual weakness $(\mathrm{Nu}=598)$ recorded the highest number of citation with an informant consensus factor of 0.95 followed by stomach aches $(\mathrm{Nu}=132)$ and malaria $(\mathrm{Nu}=175)$ with $\mathrm{ICF}$ values of 0.95 and 0.89 respectively (Table 3 ).

Table 1. Sociodemographic data of the respondents

\begin{tabular}{cl}
\hline Parameters & Respondents N(\%) \\
\hline Gender & $75(28.1)$ \\
Male & $192(71.9)$ \\
Female & \\
Age & $17(6.4)$ \\
{$[25-30]$} & $260(78.6)$ \\
{$[31-50]$} & $40(15.0)$ \\
[51-70] & \\
Educational level & $76(28.5)$ \\
Illiterate & $142(53.2)$ \\
Primary & $46(17.2)$ \\
Secondary & $3(1.1)$ \\
Superior & \\
Ethnic group & $127(47.6)$ \\
Ewe & $71(26.6)$ \\
Ouatchi & $33(12.4)$ \\
Adja & $20(7.4)$ \\
Mina & $16(6.0)$ \\
Other* & \\
Seniority & $37(13.9)$ \\
$\leq 2$ & $53(19.9)$ \\
]2-5] & $90(33.7)$ \\
]5-10] & $61(22.8)$ \\
]10-15] &
\end{tabular}


$>15$

Origin of the knowledge

Familial inheritance

Initiation from a tradional healer

Divine revelation
26(9.7)

211(79.0)

$43(16.1)$

$13(4.9)$

*Kabyè 6(2.2), Ana 3(1.1), Akposso 2(0.7), Bassar, Losso, Anago, Fon and Yorouba $1(0.35)$ each.

Table 2. Plants species used in the production of alcoholic beverages "Atikédi".

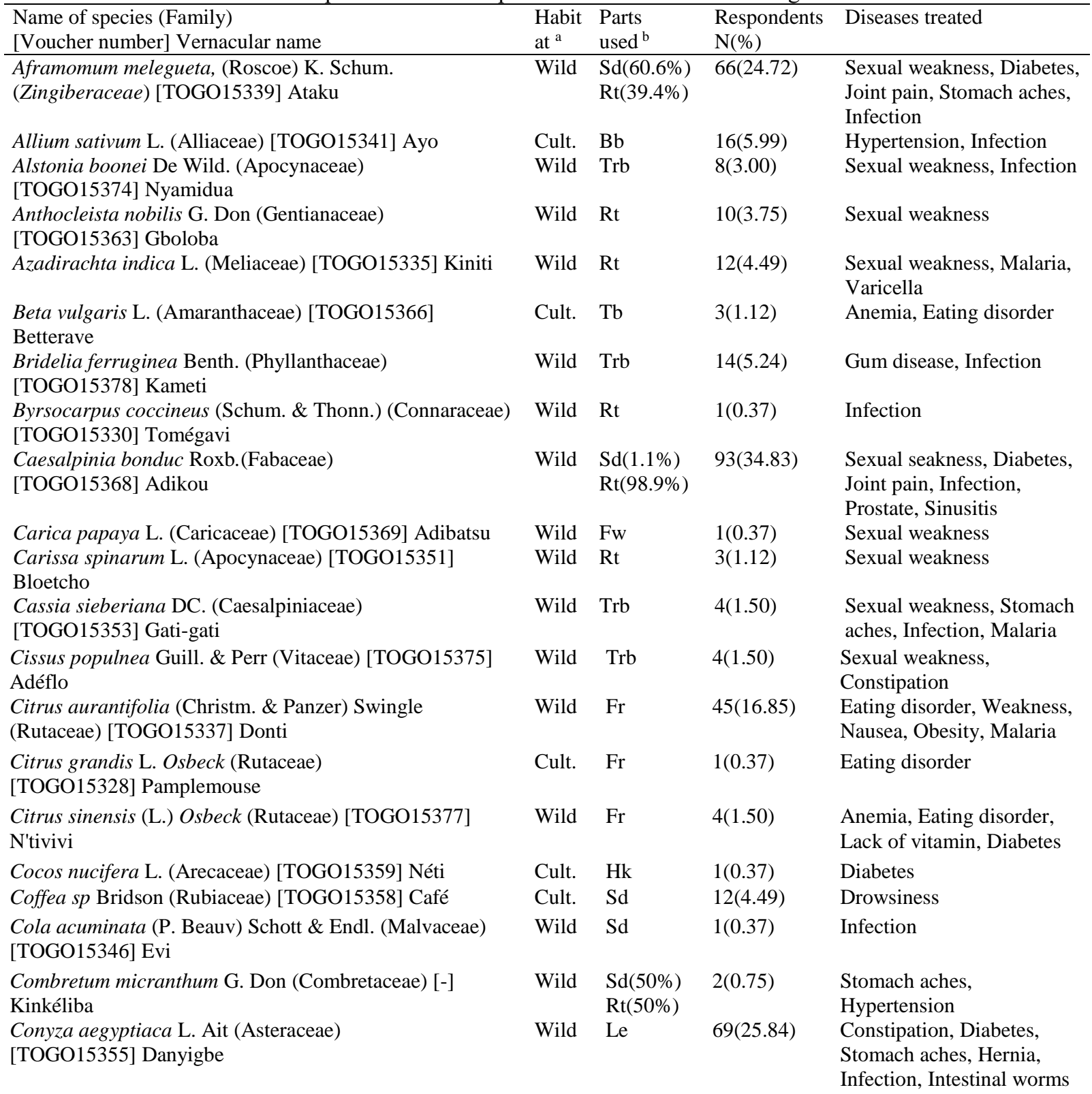


Cryptolepis sanguinolenta (Lindl.) Schltr.(Apocynaceae) Wild $\quad$ Rt [TOGO15360] Avédzitogbé

Curcuma longa L. (Zingiberaceae) [TOGO15342]

Dotèdzin

Cymbopogon citratus (DC.) Stapf (Poaceae)

[TOGO15325] Tsigbe

Cyperus esculentus var esculentus (Cyperaceae) [-] Efio

Euphorbia hirta L. (Euphorbiaceae) [TOGO15327]

Anonsikan

Garcinia kola Heckel (Clusiaceae) [TOGO15348] Ewo

Griffonia simplicifolia (Vahl ex DC.) Baill.

(Caesalpiniaceae) [TOGO15326] Gboduti

Hibiscus sabdariffa L. var. sabdariffa (Malvaceae)

[TOGO15334] Bissap

Illicium verum Hook. F. (Illiciaceae) [TOGO15345]

Badiane

Indigofera tinctoria L. (Fabaceae) [TOGO15357] Zokon

Khaya senegalensis (Desr.) A. Juss. (Meliaceae)

[TOGO15367] Mahogen

Landolphia owariensis P. Beauv. (Apocynaceae)

[TOGO15352] Cocotikpa

Lannea kerstingii A. Rich. (Anacardiaceae) [TOGO15371]

Mononkou

Laurus nobilis L. (Lauraceae)

[TOGO15365] Laurier

Mangifera indica $\mathrm{L}$. (Anacardiaceae)

[TOGO15332] Mangoti

Mezoneuron benthamianum Baill. (Leguminosae)

[TOGO15356] Wodoe-Egbigbo

Momordica charantia L. (Cucurbitaceae) [TOGO15364]

Agnagnra

Mondia whitei (Hook.F.) Skeels (Periplocaceae)

[TOGO15350] Kanabo

Monodora myristica (Gaertn.) Dunal. (Annonaceae)

[TOGO15349] Ayikou

Moringa oleifera L. (Moringaceae)

[TOGO15333] Yovovigbe

$\begin{array}{lll}\text { Wild } & \text { Rt } & 5(1.87) \\ \text { Cult. } & \text { Rz } & 3(1.12) \\ \text { Cult. } & \text { Le } & 87(32.58)\end{array}$

$\begin{array}{lll}\text { Wild } & \text { Rz } & \text { 58(21.72) } \\ \text { Wild } & \text { Ap } & 2(0.75) \\ \text { Wild } & \text { Sd } & 1(0.37) \\ \text { Wild } & \text { Rt } & 1(0.37) \\ \text { Cult. } & \text { Le } & 4(1.50) \\ \text { Wild } & \text { Fr } & 7(2.62) \\ & & \\ \text { Wild } & \text { Rt } & 1(0.37) \\ \text { Wild } & \text { Trb } & 150(56.18)\end{array}$

Wild Trb

21(7.87)

Wild Trb

21(7.87)

Wild Lst

Wild Trb

Wild Rt

Wild Lst

Wild Rt

Wild Rt

Wild Fr

Wild Rt

Wild Rt

Wild Le

Wild Trb

Cult. Fr
Appendicitis, Sexual weakness, Stomach aches, Infection

Infection

Eating disorder, Bad breath, Constipation, Hepatitis, Fever, Infection, Malaria, Nausea, Hypouresis

Eye ache, Sexual weakness Intestinal worms

Infection

Sexual weakness

Anemia, Eating disorder

Stomach aches, Premature ejaculation, Sexual weakness Infection

Anemia, Constipation,

Stomach aches, Belly wounds, Infection, Malaria, Sexual weakness

Hemorrhoid

Anemia, Infection

Constipation

Hemorrhoid, Infection

Sexual weakness

3(1.12) Sexual weakness, Varicella

201(75.28) Sexual weakness

6(2.25) Sexual weakness, Infection

67(25.09) Anemia, Eating disorder, Constipation, Diabetes, Eye ache, Stomach aches, Belly wounds, Hemorrhoid, Hypertension, Infection, Malaria, Weakness, Sexual weakness

86(32.21) Stomach aches, Malaria

2(0.75) Sexual weakness

33(12.36) Belly wounds, Infection

[TOGO15336] Esrou

Parkia biglobosa (Jacq.) R.Br. ex G.Don (Mimosaceae)

[TOGO15362] Ewotsippo

4(1.50) Infection, Sexual weakness

Phoenix dactylifera, L. (Arecaceae) [TOGO15361] Datte
$3(1.12)$
Anemia, Constipation, Sexual weakness 
Phyllanthus amarus Sch. et Th. (Phyllanthaceae)

[TOGO15331] Ehlinvi

Piper guineense Schum. \& Thonn. (Piperaceae)

[TOGO15344] Linlinkou

Senna occidentalis (L.) Link (Caesalpiniaceae)

[TOGO15376] Bessissan

Sorghum caudatum L. var. colorans (Poaceae)

[TOGO15334] Adako

Strophantus hispidus DC (Apocynaceae) [TOGO15372]

Amagan

Syzygium aromaticum (L.) Merr. \& L.M. Perry

(Myrtaceae) [TOGO15347] Plêngota

Tetrapleura tetraptera (Schumach. \& Thonn.) Taub.

(Mimosaceae) [TOGO15323] Prekese

Uvaria chamae P. Beauv (Annonaceae) [TOGO15329]

Agbanla

Vetiveria nigritana (Benth.) Stapf (Poaceae)

[TOGO15373] Kédéké

Vitex doniana (Sweet) (Verbenaceae)

[TOGO15320] Efontsi

Waltheria indica L. (Malvaceae)

[TOGO15370] Adouwèti

Xylopia aethiopica (Dunal) A. Rich. (Annonaceae)

[TOGO15343] Etso

Zanthoxylum xanthoxyloides (Lam.) Zepernick \& Timler (Rutaceae) [TOGO15321] Xeti

Zea mays L. (Poaceae) [TOGO15340] Ebliti Zingiber officinale (Roscoe) (Zingiberaceae) [TOGO15322] Dotè

\begin{tabular}{|c|c|c|c|}
\hline Wild & Wp & $97(36.33)$ & $\begin{array}{l}\text { Constipation, Stomach aches, } \\
\text { Belly wounds, Hernia, } \\
\text { Infection, Intestinal worms }\end{array}$ \\
\hline Wild & $\mathrm{Fr}$ & $11(4.12)$ & Infection \\
\hline Wild & $\begin{array}{l}\operatorname{Rt}(60 \% \\
\operatorname{Sd}(40 \%\end{array}$ & $10(3.75)$ & $\begin{array}{l}\text { Hepatitis, Infection, Sexual } \\
\text { weakness, Sickle cell, Skin rash }\end{array}$ \\
\hline Cult. & Le & $102(38.20)$ & $\begin{array}{l}\text { Anemia, Eating disorder, Lack } \\
\text { of vitamin, Infection, Malaria }\end{array}$ \\
\hline Wild & Rt & $5(1.87)$ & Infection, Sexual weakness \\
\hline Wild & $\mathrm{Sd}$ & $72(26.97)$ & $\begin{array}{l}\text { Belly wounds, Stomach aches, } \\
\text { Infection, Sexual weakness }\end{array}$ \\
\hline Wild & Fr & $27(10.11)$ & $\begin{array}{l}\text { Anemia, Eating disorder, Lack } \\
\text { of vitamin, Constipation, } \\
\text { Stomach aches, Infection }\end{array}$ \\
\hline Wild & Rt & $3(1.12)$ & Infection, Sexual weakness \\
\hline Wild & Rt & $152(56.93)$ & $\begin{array}{l}\text { Hepatitis, Infection, Stomach } \\
\text { aches, Gum disease, Lower } \\
\text { abdominal pain, Premature } \\
\text { ejaculation, Prostate, Sexual } \\
\text { weakness, Urinary tract } \\
\text { infection }\end{array}$ \\
\hline Wild & Trb & $3(1.12)$ & Sexual weakness \\
\hline Wild & Rt & $80(29.96)$ & $\begin{array}{l}\text { Abortion, Irregular } \\
\text { menstruation, Stomach aches, } \\
\text { Infection, Infertility, Joint pain, } \\
\text { Malaria, Lower abdominal } \\
\text { pain, Weakness, Premature } \\
\text { ejaculation, Sexual weakness }\end{array}$ \\
\hline Wild & Fr & $164(61.42)$ & $\begin{array}{l}\text { Hernia, Hypertension, } \\
\text { Infection, Stomach aches, Belly } \\
\text { wounds, Sexual weakness }\end{array}$ \\
\hline Wild & $\begin{array}{l}\operatorname{Rt}(96.4 \\
\%) \\
\operatorname{Trb}(3.6 \\
\%)\end{array}$ & $55(20.60)$ & $\begin{array}{l}\text { Difficult childbirth, Stomach } \\
\text { aches, Belly wounds, Gum } \\
\text { disease, Infection, Sexual } \\
\text { weakness, Tooth decay, } \\
\text { Prostate }\end{array}$ \\
\hline Cult. & St & $1(0.37)$ & Diarrhea \\
\hline Wild & $\mathrm{Rz}$ & 190(71.16) & $\begin{array}{l}\text { Sore throat, Cold, Cough, } \\
\text { Stomach aches, Belly wounds, } \\
\text { Infection, Sexual weakness }\end{array}$ \\
\hline
\end{tabular}

${ }^{a}$ Habitat: Cult. Cultivate. ${ }^{b}$ Part used: Ap, Arial part; Bd, Bulb; Fr, Fruit; Fw, Flower; Hk, Husk; Le, Leave; Lst, leafy steam; Rt, Root; Rz, Rhizome; Sd, Seed; St, Stalk; Tb, Tuber; Trb, Trunk bark; Wp, Whole plant. 
Table 3. The recorded ailments grouped per categories.

\begin{tabular}{|c|c|c|c|c|}
\hline Ailment categories & Ailments & $\begin{array}{l}\text { Number of } \\
\text { citations (Nuc) }\end{array}$ & $\begin{array}{l}\text { Number of } \\
\text { plants species } \\
\text { used (Ns) }\end{array}$ & $\begin{array}{l}\text { Informant Consensus } \\
\text { Factor (ICF) }\end{array}$ \\
\hline Childbirth problems & $\begin{array}{l}\text { Difficult } \\
\text { childbirth }\end{array}$ & 1 & 1 & - \\
\hline \multirow[t]{3}{*}{ Circulatory diseases } & Anemia & 82 & 10 & 0.89 \\
\hline & Hemorrhoid & 23 & 3 & 0.91 \\
\hline & Hypertension & 9 & 4 & 0.63 \\
\hline Contraception & Abortion & 1 & 1 & - \\
\hline \multirow{2}{*}{ Dentistry } & Gum disease & 11 & 4 & 0.70 \\
\hline & Bad breath & 22 & 1 & 1.00 \\
\hline Dermatological problems & Skin rash & 6 & 1 & 1.00 \\
\hline Eye problems & Eye ache & 2 & 2 & 0.00 \\
\hline Female problems & $\begin{array}{l}\text { Irregular } \\
\text { mentruation }\end{array}$ & 1 & 1 & - \\
\hline Fertility problems & Infertility & 1 & 1 & - \\
\hline \multirow[t]{7}{*}{ Gastro-intestinal problems } & Eating disorder & 52 & 9 & 0.84 \\
\hline & Constipation & 27 & 9 & 0.69 \\
\hline & Diarrhea & 1 & 1 & - \\
\hline & Stomach aches & 132 & 16 & 0.89 \\
\hline & Hernia & 6 & 3 & 0.60 \\
\hline & Nausea & 3 & 2 & 0.50 \\
\hline & Belly wounds & 23 & 8 & 0.68 \\
\hline Hemoglobinopathies & Sickle cell & 1 & 1 & - \\
\hline \multirow[t]{3}{*}{ Infection (Bacterial) } & $\begin{array}{l}\text { Infection } \\
\text { (Unspecified) }\end{array}$ & 668 & 34 & 0.95 \\
\hline & Tooth decay & 3 & 1 & 1.00 \\
\hline & $\begin{array}{l}\text { Urinary tract } \\
\text { infection }\end{array}$ & 1 & 1 & - \\
\hline Infection (Viral) & Varicella & 3 & 2 & 0.50 \\
\hline \multirow[t]{5}{*}{ Inflammations and pains } & Appendicitis & 1 & 1 & - \\
\hline & Fever & 1 & 1 & - \\
\hline & Joint pain & 3 & 3 & 0.00 \\
\hline & $\begin{array}{l}\text { Lower abdominal } \\
\text { pain }\end{array}$ & 3 & 2 & 0.50 \\
\hline & Prostate & 18 & 3 & 0.88 \\
\hline Liver problems & Hepatitis & 3 & 3 & 0.00 \\
\hline \multirow[t]{2}{*}{ Male fertility problems } & $\begin{array}{l}\text { Premature } \\
\text { ejaculation }\end{array}$ & 7 & 3 & 0.67 \\
\hline & Sexual weakness & 598 & 32 & 0.95 \\
\hline \multirow[t]{2}{*}{ Metabolic disorders } & Diabetes & 5 & 5 & 0.00 \\
\hline & Obesity & 1 & 1 & - \\
\hline \multirow[t]{2}{*}{ Neurological disorders } & Drowsiness & 12 & 1 & 1.00 \\
\hline & Weakness & 5 & 3 & 0.50 \\
\hline Nutritional disorders & Lack of vitamin & 3 & 3 & 0.00 \\
\hline Parasitic intestinal & Intestinal worms & 89 & 3 & 0.98 \\
\hline
\end{tabular}




\begin{tabular}{lllll}
\hline Parasitic sanguicole & Malaria & 175 & 10 & 0.95 \\
Respiratory problems & Cold & 5 & 1 & 1.00 \\
& Cough & 4 & 1 & 1.00 \\
& Sore throat & 2 & 1 & 1.00 \\
& Sinusitis & 1 & 1 & - \\
Urinary problems & Hypouresis & 5 & 2 & 0.75 \\
\hline
\end{tabular}

Nuc, Number of citations in each category; Ns, Number of species used; ICF, Informant consensus factor.

\section{Discussion}

Sociodemographic data

The production of the local alcoholic beverages "Atikédi" has been part of traditional medicine practice since producers use plants for medicinal purposes. This study showed that this practice is the preserve of adults (3170) since they represent $93.6 \%$ of the respondents (210/267). These results are in accordance with previous studies which revealed the predominance of senior adults (Kpodar et al., 2017; Aburjai et al., 2007). The results also indicated that $79.0 \%$ of the respondents acquired their medicinal practice knowledge as a family inheritance and $16.1 \%$ from a traditional healer's initiation. Moreover, the respondents had a good experience in the field since $33.7 \%$ and $22.8 \%$ had respectively experience ranging from 5 to 10 years and 10 to 15 years in the production of beverages.

Regarding the educational level, 53.2\% of the respondents had a primary educational level followed by $28.5 \%$ of non-literates. These results show that the literacy level of the majority of the respondents is rather low. Despite the educational level, this does not impede the acquisition of herbal medicinal pratices (Kpodar et al., 2017) but it is a parameter that allows the researchers to understand easily their ability in the field. Indeed, non-literates mentioned as diagnosis "infection" but were not able to locate the anatomic site of the infection or to distinguish between microbial or viral infection (Table 3). As a result, this fact is a limit of this study.

In this study, there were 192 women recorded compared to 75 men (Table 1); with a sex ratio (F/M) of 3 reflecting a slight predominance of women in this activity, unlike traditional healers who were mostly men (Aburjai et al., 2007). This predominance of women is explained by the fact that the production of beverages was not the unique activity of practitioners because it was coupled with the direct sale of the local drink "Sodabi" in kiosks. The large representation of Ewe and Ouatchi ethnic groups can be explained not only by the fact that the survey was conducted in Lomé, which is more populated by these two ethnic groups (DGSNA, 2011), but also, Ewe 
and Ouatchi have had an old tradition in the production and consumption of these beverages (Tchacondo, 2011).

\section{Frequency of plant species and ailments}

This study aimed at making an inventory of plant species used in production of the local alcoholic beverages "Atikédi" in Lomé. It was a new insight given by the study compared to earlier ethnobotanical studies which have been undertaken on plants used against specific diseases such as malaria, fungal infection, diabetes and hypertension.

The study has recorded 61 medicinal plant species belonging to 58 genera and 35 families. The most represented family was Apocynaceae with 5 plant species followed by Rutaceae and Poaceae with 4 plant species. This study showed also that Apocynaceae and Poaceae have been identified as the most frequently plant families used in the management of infections according to Hoekou et al. (2016), Karou et al. (2012) and in the management of sexual weakness according to Sunmonu et al. (2015). Rutaceae is mainly used in the treatment of malaria according to Agbodeka et al. (2016) and Koudouvo et al. (2011). However, Hernández et al. (2004) reported more plants in the Eastern Region of Cuba. Indeed they reported 170 species used in the preparation of 199 plant mixtures belonging to 71 families. Among them Fabaceae, Poaceae and Rutaceae have high prevalences. These results are close to what we found for the most represented families.

The producers of "Atikédi" used medicinal plants to treat a wide range of ailments. In fact, the 61 plants species recorded were used in management of 43 diseases (Table 3). Among these plants, the highest record was $41.0 \%$ species used to treat one ailment, followed by $26.2 \%$ species which were used to treat two ailments. The fruits of Moringa oleifera were used to treat 13 different ailments and the roots of Waltheria indica were used to treat 11 different ailments. The leaves of Cymbopogon citratus and the roots of Vetiveria nigritana were used to treat 9 ailments. Both roots (96.4\%) and trunk barks (3.6\%) of Zanthoxylum xanthoxylö̈des were used to treat 8 ailments. Caesalpinia bonduc (roots $98.9 \%$ and seeds $1.1 \%$ ); trunk barks of Khaya senegalensis were used to treat 7 ailments. The use of one species to treat many diseases indicated the plurality of the active compounds contained in plants (Balayogan et al., 2014). Although the root of Mondia whitei Skeels was used only for the management of sexual weakness, it remained the most used plant species recorded, with a frequency of citation of $75.28 \%$ (Table 2). This could be due to the fact that the root of 
Mondia whitei is a traditional plant containing aphrodisiac potentials (Oketch-Rabah. 2012; Chauhan et al., 2014) and contains androgenic property (Watcho et al., 2004).

Bacterial infections and sexual weakness were the most recorded pathologies with respectively 672 citations and 598 citations (Table 3) followed by malaria and stomach aches. Malaria accounted for 175 citations with 10 plants species used. Intestinal worms, anemia and eating disorder were also mentioned with 89 citations and 3 plants species used for intestinal worms, 82 citations and 10 plants species used for anemia, 52 citations and 9 plants species used for eating disorder. Finally, constipation, hemorrhoid, belly wounds and bad breath were identified. Constipation accounts for 27 citations and 9 plants species used; belly wounds for 23 citations and 8 plants species used; hemorrhoid for 23 citations and 3 plants species used; and bad breath for 22 citations with only 1 plant species used. Diseases like prostate, drowsiness, hypertension and gum disease were less recorded. Indeed, 4 plants species were used for gum disease and hypertension and 3 plants species for prostate. In fact, although people used "Atikédi" for many medical purposes in Lomé, bacterial infection and sexual weakness remained the most important diseases for which these beverages were used.

A concern in this study is the issue of the dose administered. This is one of the major problems with traditional medicine (Karou et al., 2011). In fact "Atikédi" producers declared that the doses depend on each person's ability to withstand alcohol. Alcohol having its toxicity, the ideal would be to use it just as an extraction solvent and to avoid drinking it as part of a plantbased treatment. This fact challenges the researchers to check whether a water infusion could give the same effects.

\section{Conclusion}

The study pointed out that beverages producers were in fact tradional healers due to their knowledge on medicinal plants that they used for therapeutic purposes. The beverages recorded were prepared with medicinal plants mainly contained in the pharmacopoeia of West Africa. Our hypothesis is justified by the fact that the area of production of these beverages is full of information about plants whose management will contribute to the improvement of traditional medicine in Togo, Africa and the whole world. Pharmacological and toxicological studies will be certainly necessary to assess the roles that most of these plants play in healing diseases not only in prospected populations but also in the world. 


\section{Declaration of conflict of interest}

We declare to have no conflict of interest.

\section{Acknowledgments}

The authors are cordially grateful to the informants for sharing with them their precious traditional knowledge. They are also thankful to the Herbarium of the University of Lomé (Herbarium_togoense) at the Department of Botany which serves as the National Herbarium, especially Professor Akpagana Koffi and Mr Sodjinou Komlan Edjèdu for plant specimen identification. They are finally grateful to the Ministry of Health who gave its approval for the research to be conducted in Lomé.

\section{References:}

1. Aburjai, T., Hudaib, M., Tayyem, R., Yousef, M., \& Qishawi, M., (2007). Ethnopharmacological survey of medicinal herbs in Jordan, the Ajloun Heights Region. Journal of Ethnopharmacology, 110(2), 294-304.

2. Adjanohoun, E.J., Adjakidje, V., Ahyi, M.R.A., Ake Assi L., Akoegninou, A., d'Almeida, J., Apovo, F., Boukef, K., Chadare, M., Cusset, G., Dramane, K., Eymé, J., Gassita, J.N. Gbaguidi, M., Goudote, E., Guinko, S., Houngnon, P., Issa, Lo., Keita, A., Kiniffo, H.V., Kone-Bamba, D., Musampa Nseyya, A., Saadou, M., Sodogandgi, Th., de Souza, S., Tchabi, A., Zinsou Dossa, C., \& Zohoun, Th., (1989). Contribution aux études ethnobotaniques et floristiques en République Populaire du Bénin. Collection Médecine Traditionnelle et Pharmacopée. Agence de Coopération Culturelle et Technique. 895p.

3. Attah, A.F., Hellinger, R., Sonibare, M.A., Moody J.O., Arrowsmith, S., Wray S., \& Gruber C.W. (2016). Journal of Ethnopharmacology, 179, 83-91.

4. Ayayi, C.O., Elujoba, A.A., Bejide, R.A., Akinloye, J.A., \& Omonisi, A.E., (2015). Toxicity and pharmacognostic standards for laxative properties of Nigerian Cassia sieberiana and Senna obtusifolia roots. European Journal of Medicinal Plants, 6(2), 110-123.

5. Balayogan S., Marimatha A., \& Perumal, G., (2014). An ethnobotanical study of indigenous knowledge on medicinal plants used by the village peoples of Thoppampatti, Dindigul district, Tamilnadu, India. Journal of Ethnopharmacology, 153, 408-423.

6. Chauhan,N.S., Sharma, V., Dixit, V. K., \& Thakur, M., (2014). A review on plants used for improvement of sexual performance and virility. BioMed Research International, 2014, 1-19. 
7. Directorate General of Statistics and National Accounts Togo, (2011). Togo Population and Housing Census 2010.

8. Gbekley, H.E., Karou, S.D., Katawa, G., Tchacondo, T., Batawila, K., Ameyapoh, Y., \& Simpore, J., (2018). Ethnobotanical survey of medicinal plants used in the management of hypertension in the Maritime Region of Togo. African Journal of Traditional, Complementary and Alternative Medicine, 15(1), 85-97.

9. Gupta, M., Mazumber, U.K., Kumar, R.S., Sivakumar, T., Gomathi, P., \& Rajeshwar, Y., (2004). Antioxidant defense system induced by a methanol extract of Caesalpinia bonducella in rat liver. Journal of Pharmacology Sciences, 43(5), 411-419.

10. Heinrich, M., Ankli, A., Frei, B., Weimann, C., \& Sticher, O., (1998). Medicinal plants in Mexico: healers' consensus and cultural importance. Social Science and Medicine, 47, 1859-1871.

11. Hoekou, Y.P., Tchacondo, T., Karou, D.S., Koudouvo, K., Atakpama, W., Pissang, P., Gbogbo, A.K., Woegan, A.Y., Batawila, K., Akpagana, K., \& Gbeassor, M., (2016). Ethnobotanical study of latex plants in the maritime region of Togo. Pharmacognosy Research, 8, 128-134.

12. Karou, S.D., Tchacondo, T., Tchibozo, M.A.D., Abdoul-Rahaman, S., Anani, K., Koudouvo, K. Batawila, K., Agbonon, A., Simpore, J., \& de Souza, C., (2011). Ethnobotanical study of medicinal plants used in the management of diabetes mellitus and hypertension in the Central Region of Togo. Pharmaceutical Biology, 49(12), 12861297.

13. Karou, S.D., Tchacondo, T., Tchibozo, M.A.D., Anani, K., Ouattara, L., Simpore, J., \& de Souza, C., (2012). Screening Togolese medicinal plants for few pharmacological properties. Pharmacognosy Research, 4(2), 116.

14. Koudouvo, K., Esseh, K., Denou, A., Aziati, T., Ajavon, C., Afanyibo, Y-G., Agbonon, A., Sanogo, R., Dougnon, J., Aklikokou, K., Aguiyi, J-C., Diallo, D., Mensah, G.A., \& Gbeassor, M., (2016). Étude ethno-pharmacologique des recettes médicinales antipaludiques du Togo pour la formulation d'un phytomédicament de prise en charge du paludisme. Bulletin de la Recherche Agronomique du Bénin, 79, 54-70.

15. Koudouvo, K., Karou, D.S., Kokou, K., Essien, K., Aklikokou, K., Glitho, K., Simpore, J., Sanogo, R., de Souza, C., \& Gbeassor, M., (2011). An ethnobotanical study of antimalarial plants in Togo Maritime Region. Journal of Ethnopharmacology, 134, 183-190. 
16. Kunwar, R.M., Uprety, Y., Burlakoti, C., Chowdhary, C.L., \& Bussmann, R.W. (2009). Ethnobotany Research and Applications, 7, 005-028.

17. Njoroge, N.G., \& Bussmann, W.R., (2007). Ethnotherapeutic management of skin diseases among the Kikuyus of Central Kenya. Journal of Ethnopharmacology, 111, 303-307.

18. Odonne, G., Bourdy, G., Beauchêne, J., Houël, E., Stien, D., Chevolot, L., \& Deharo, E., (2007). From Tonic-cups to Bitter-cups: Kwasi bita beker from Suriname Determination, past and present use of an ancient galenic artefact. Journal of Ethnopharmacology, 110, 318-322.

19. Oketch-Rabah, H.A., (2012). Mondia whitei, a medicinal plant from Africa with aphrodisiac and antidepressant properties: a review. Journal of Dietary Supplements, 9(4), 272-284.

20. Soejarto, D.D., Gyllenhaal, C., Kadushin, M.R., Southavong, B., Sydara, K., Bouamanivong, S., Xaiveu, M., Zhang, H.-J., Franzblau, S.G., Ghee, T. Tan, Pezzuto, J.M., Riley, M.C., Elkington, B.G., \& Waller, D.P., (2012). An ethnobotanical survey of medicinal plants of Laos toward the discovery of bioactive compounds as potential candidates for pharmaceutical development. Pharmaceutical Biology, 50(1), 42-60.

21. Sunmonu, T.O., Ugbaja, R.N., Ogunlesi, O., Olafimihan, D., Shodeinde, T., Toriola, M.A., \& Balogun, E.A., (2015). Effects of Strophanthus hispidus DC. (Apocynaceae) aqueous root extract on antioxidant status in Streptozotocin-induced diabetic rats. Biokemistri, 27(2), 89-97.

22. Tchacondo, T., Karou, S.D., Agban, A., Bako, M., Batawila, K., Bawa, M.L., Gbeassor, M., \& de Souza, C., (2012). Medicinal plants used in the central Togo (Africa) with an emphasis on the timing. Pharmacognosy Research, 4(2), 92-103.

23. Totelin, L., (2015). When foods become remedies in ancient Greece: The curious case of garlic and other substances. Journal of Ethnopharmacology, 167, 30-37.

24. Volpato, G., Godínez, D., \& Beyra, A., (2009). Migration and ethnobotanical practices: The case of Tifey among Haitian immigrants in Cuba. Human Ecology, 37, 43-53.

25. Watcho, P., Kamtchouing, P., Sokeng, S.D., Moundipa, P.F., Tantchou, J., Essame, J.L., \& Koueta, N., (2004). Androgenic effect of Mondia whitei roots in male rats. Asian Journal of Andrology, 6, 269-272. 